\title{
Determination of Silicic Acid in Highly Purified Water by Improved Gel-Phase Absorptiometry
}

\author{
Ushio HASE* and Kazuhisa YoshIMURA** \\ * Resources \& Environment Protection Research Laboratories, NEC Corp., \\ Miyazaki, Miyamae, Kawasaki 216, Japan \\ ** Chemistry Laboratory, College of General Education, Kyushu University, \\ Ropponmatsu, Fukuoka 810, Japan
}

\begin{abstract}
Gel-phase absorptiometry has been improved for determining silicic acid in highly purified water, in which the absorbance of Molybdenum Blue adsorbed on Sephadex G-25 is measured directly. The gel amount used was reduced to one-sixth of that required in the previously reported method by employing a smaller volume cell and a gel-aliquotting device. Less than $0.05 \mathrm{~g}$ of the gel could be measured rapidly with good reproducibility and the detection limit of silicon was $0.04 \mu \mathrm{g}$ $\mathrm{dm}^{-3}$.
\end{abstract}

Keywords Gel-phase absorptiometry, silicic acid, Molybdenum Blue, highly purified water

In the process of producing highly purified water, silicic acid is one of the most difficult components to remove. Usually it begins to leak first from an exhausted mixed-bed ion-exchanger column. Although many sensitive analytical methods have been developed to measure lower concentrations of silicic acid, almost all of these methods require expensive equipment and/or time-consuming preconcentration steps. A very sensitive gel-phase absorptiometry, based on direct light absorption measurement for the Molybdenum Blue species concentrated on Sephadex G-25 gel, has been reported, whereby silicic acid at $\mu \mathrm{g} \mathrm{dm}^{-3}$ levels can be determined in a conveniently short time using $100 \mathrm{~cm}^{3}$ water samples. ${ }^{1}$

Sensitivity in solid-phase absorptiometry can be improved by using a cell with longer light path or employing a larger solution-to-solid volume ratio system. The purpose of this work to show how to make the gelphase absorptiometry more sensitive and easier to operate, by employing a smaller volume cell and a gelaliquotting device.

\section{Experimental}

\section{Reagents}

Unless otherwise noted, all reagents used were of analytical grade. Deionized water, prepared by a MilliQ SP system (Millipore), was used throughout. Highly purified water, prepared with a commercially available poly(tetrafluoroethylene) (PTFE) subboiling distillation apparatus (Fujiwara Factory), was used as water, free from silicic acid.
Standard silicic acid solution, $1000 \mathrm{mg} \mathrm{dm}^{-3}$ of $\mathrm{Si}$ (Wako, Osaka).

An ammonium molybdate-sulfuric acid solution was prepared by dissolving $50 \mathrm{~g}$ of $\left(\mathrm{NH}_{4}\right)_{6} \mathrm{Mo}_{7} \mathrm{O}_{24} \cdot 4 \mathrm{H}_{2} \mathrm{O}$ (Wako) in about $100 \mathrm{~cm}^{3}$ of water, mixing the solution with $120 \mathrm{~cm}^{3}$ of water containing $35 \mathrm{~cm}^{3}$ of concentrated sulfuric acid, and then diluting the solution to $250 \mathrm{~cm}^{3}$ with water.

A $10 \%(\mathrm{~m} / \mathrm{v}) \mathrm{L}$-ascorbic acid solution was prepared by dissolving $10 \mathrm{~g}$ of L-ascorbic acid (Wako) in $100 \mathrm{~cm}^{3}$ of water.

A $12 \mathrm{~mol} \mathrm{dm}^{-3}$ sulfuric acid solution was prepared by mixing $150 \mathrm{~cm}^{3}$ of water with $300 \mathrm{~cm}^{3}$ of concentrated sulfuric acid (electronics grade; Kanto Tokyo).

Sephadex G-25, Fine (Pharmacia, Uppsala).

\section{Apparatus}

Light measurements were made with a Hitachi Model U-3200 double-beam recording spectrophotometer. A perforated metal plate, whose attenuance was 1 , was inserted in a reference beam to balance the light intensities. A cell (Nippon Sekiei Glass) has black sides, with a 5-mm path length and a 4-mm sample space width. A $3.5-\mathrm{mm}$ height adjuster was adhered at the bottom of the cell, in order to settle the gel in only the cell portion where the light passes through (Fig. 1(a)). Alternatively, a small-volume flow cell supplied by Nippon Quartz Glass can be used. The cell, with black sides, a $5 \mathrm{~mm}$ path length and $0.035 \mathrm{~cm}^{3}$ cell volume, was fitted with a polypropylene filter tip to retain the gel in the cell, as shown in Fig. 1(b).

The gel was measured with a gel-aliquotting device, shown in Fig. 2. A PTFE tube (2-mm i.d. and $35 \mathrm{~mm}$ 


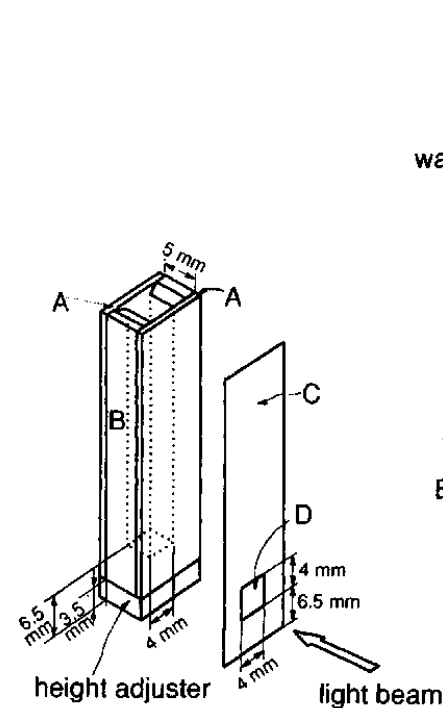

(a)

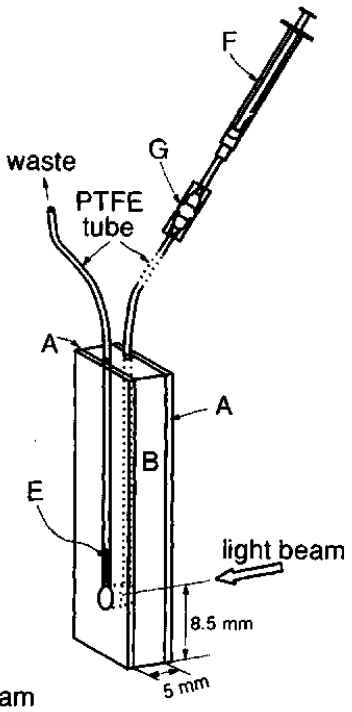

(b)

Fig. 1 Cells for gel-phase absorptiometry. (a), black cell with height adjuster; (b), micro black flow cell with a light path of $3 \mathrm{~mm} \phi \times 5 \mathrm{~mm}$. Two transparent fused silica glass plates ( $1 \mathrm{~mm}$ in thickness), A, are pasted on both sides of the black glass cell ( $5 \mathrm{~mm}$ in thickness), B. The black plate, C, has a light window $(4 \mathrm{~mm} \times 4 \mathrm{~mm}), \mathrm{D} ; \mathrm{E}$, poly(propylene) filter tip; F, disposable syringe; $G$, PCTFE joint.

(a)

(b)

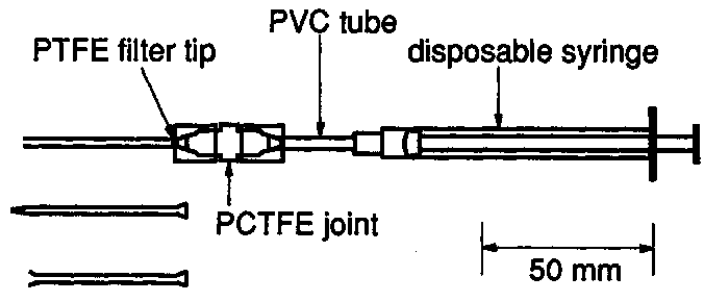

(c)

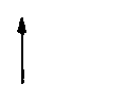

PTFE tube(2mm-i.d., 3mm-o.d.)

Fig. 2 Gel-aliquotting device. PTFE, poly(tetrafluoroethylene); PVC, poly(vinyl chloride); PCTFE, poly(chlorotrifluoroethylene).

long), was fitted on one side with a PTFE resin filter tip and connected with a disposable syringe.

\section{Procedure for determination of silicic acid in highly purified water}

To a $100-\mathrm{cm}^{3}$ sample solution containing 5 to $100 \mathrm{ng}$ of silicate-silicon in a poly (methylpentene) container, $2 \mathrm{~cm}^{3}$ of the ammonium molybdate-sulfuric acid solution was added. The solution was allowed to stand for $15 \mathrm{~min}$. Then, $10 \mathrm{~cm}^{3}$ of the sulfuric acid solution and $1 \mathrm{~cm}^{3}$ of the ascorbic acid solution were added to the solution. Then the gel was added to the solution with the aliquotting device. After the mixture was stirred for $20 \mathrm{~min}$, the colored gel beads were allowed to settle. Then, with a pipet, the gel was collected and transferred to the cell (Fig. 1(a)). When the cell shown in Fig. 1(b) was used, a $10-\mathrm{cm}^{3}$ disposal syringe for collecting the colored gel beads was connected with the flow cell with a PCTFE (poly(chlorotrifluoroethylene)) joint, and then the gel beads were transferred to the flow cell. The cell was set in an ordinary holder in the spectrophotometer. The absorbances at $805 \mathrm{~nm}$ and $450 \mathrm{~nm}$ were measured against air as reference. The net absorbance $\left(A_{\text {Net }}\right)$ for the blue species of molybdosilicate adsorbed on the gel at $805 \mathrm{~nm}$, was obtained from the difference between two absorbances $(\triangle A)$, minus the corresponding difference for the blank ( $\triangle A$ (for the blank)).

\section{Distribution measurements}

The reagents were added to $100-\mathrm{cm}^{3}$ water samples containing $0.5 \mu \mathrm{g}$ of silicate-silicon in the same manner as described above. The solutions were allowed to stand for $15 \mathrm{~min}$. Then various amounts of the gel were added. The mixtures were stirred for $20 \mathrm{~min}$ and allowed to settle. The gel adsorbing the blue species in each mixture was collected and light measurement was made in the same manner as described above.

\section{Reproducibility measurement of the gel-aliquotting device}

The gel slurry was measured by the aliquotting device and transferred to a poly(propylene) resin weighing bottle. The gel was allowed to stand in a desiccator for two days. The gel was further dried by a CEM microwave digestion system, Model MDS 81D, until a constant weight was reached.

\section{Results and Discussion}

\section{Absorption spectra}

Figure 3 shows the absorption spectra of the molybdosilicate blue species in gel phase and solution phase. In spite of the difference in reducing agents (1amino-2-naphthol-4-sulfuric acid for the previously reported method ${ }^{1}$ and L-ascorbic acid for the present study), the gel-phase spectrum is the same.

Using the absorbance difference $(\Delta A)$ makes the solidphase absorptiometry highly precise (vide supra).

\section{Gel amount measured by the gel-aliquotting device}

It is difficult to weigh a small and constant amount of gel due to the hygroscopic property of the gel. To achieve higher reproducibility and more rapid, easier operation than the previously reported method, the PTFE apparatus, shown in Fig. 2, was designed. The relative standard deviations in the gel amounts, aliquotted by the device with different PTFE tube shapes, were $0.83 \%$ ( 5 runs) for (a), $0.87 \%$ ( 5 runs) for (b), and $1.8 \%$ (8 runs) for (c) in Fig. 2: tube (a) is the best. The average amount aliquotted was $0.0326 \mathrm{~g}$. This corresponds to $0.168 \mathrm{~cm}^{3}$ of swollen gel. By using the device, less than $0.05 \mathrm{~g}$ of the gel can be measured rapidly with good reproducibility. 


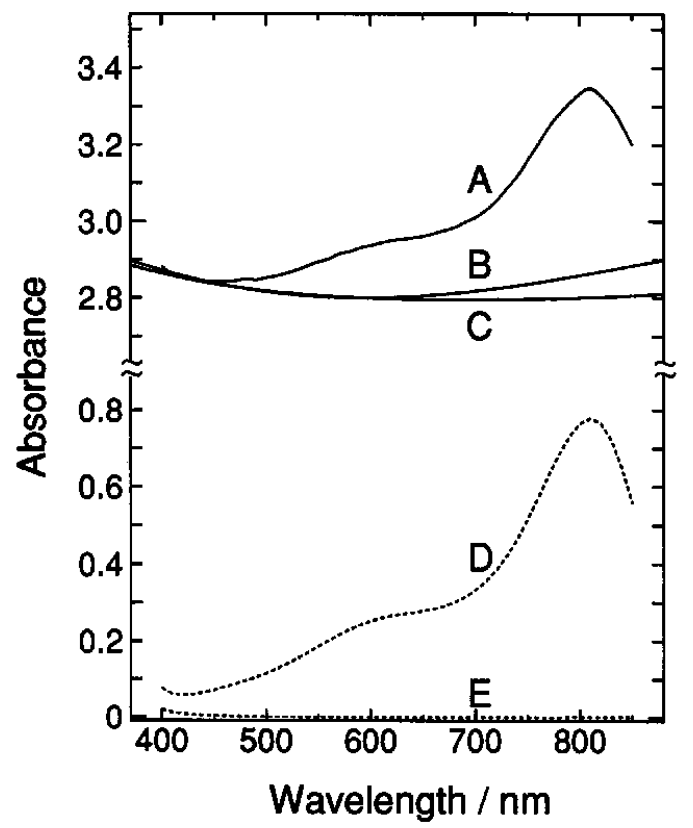

Fig. 3 Absorption spectra of molybdosilicic acid (Molybdenum Blue). Solid lines, gel phase spectra; cell, black cell described above; gel, Sephadex G-25, $0.0326 \mathrm{~g}$; solution, $100 \mathrm{~cm}^{3}$; A, $4 \mu \mathrm{g} \mathrm{dm}^{-3} \mathrm{Si}$; , reagent blank; C, gel itself. Dotted lines, solution phase spectra; cell, $10 \mathrm{~mm} ; \mathrm{D}, 1 \mathrm{mg}$ $\mathrm{dm}^{-3} ; \mathrm{E}$, reagent blank.

\section{Molybdosilicic acid adsorption}

The distribution ratio of molybdosilicic acid is expressed as the Eq. (1):

$$
D=\frac{C_{\mathrm{i}}-C_{\mathrm{f}}}{C_{\mathrm{f}}} \frac{V}{V_{\mathrm{g}}}
$$

where $C_{\mathrm{i}}\left(\mathrm{mol} \mathrm{dm}^{-3}\right)$ is the initial silicate-silicon concentration, $C_{\mathrm{f}}\left(\mathrm{mol} \mathrm{dm}^{-3}\right)$ the final silicate-silicon concentration in the equilibrated solution, $V\left(\mathrm{~cm}^{3}\right)$ the sample volume, and $V_{\mathrm{g}}\left(\mathrm{cm}^{3}\right)$ the total swollen gel volume. Net absorbance for the equilibrated gel, $A_{\text {Net }}$, is expressed as Eq. (2):

$$
\begin{aligned}
A_{\text {Net }} & =\bar{\varepsilon} \bar{l}[\text { molybdosilicic acid }]_{\mathrm{g}}=\bar{\varepsilon} \bar{l}\left(C_{\mathrm{i}}-C_{\mathrm{f}}\right) \frac{V}{V_{\mathrm{g}}} \\
& =\bar{\varepsilon} \bar{l} D \frac{V}{D V_{\mathrm{g}}+V} C_{\mathrm{i}}
\end{aligned}
$$

where $\bar{\varepsilon}$ is the molar absorptivity for the molybdosilicic acid in the gel phase, $\bar{l}$ is the average light-path length through the gel phase, and [molybdosilicic acid] $]_{8}$ $\left(\mathrm{mol} \mathrm{dm} \mathrm{dm}^{-3}\right)$ is the molybdosilicic acid concentration in the gel phase. $\bar{l}$ is about one-half of the light path length of a cell, $l .^{2}$ Equation (2) can be modified to Eq. (3):

$$
\frac{1}{A_{\mathrm{Net}}}=\frac{1}{\bar{\varepsilon} \bar{l} V C_{\mathrm{i}}} V_{\mathrm{g}}+\frac{1}{\bar{\varepsilon} \bar{l} C_{\mathrm{i}}} \frac{1}{D}
$$

Figure 4 shows a plot for the reciprocal of the $A_{\text {Net }}$ versus $V_{\mathrm{g}}$, where $V$ is $100 \mathrm{~cm}^{3}, C_{\mathrm{i}}$ is $1.8 \times 10^{-7} \mathrm{~mol} \mathrm{dm}^{-3}$,

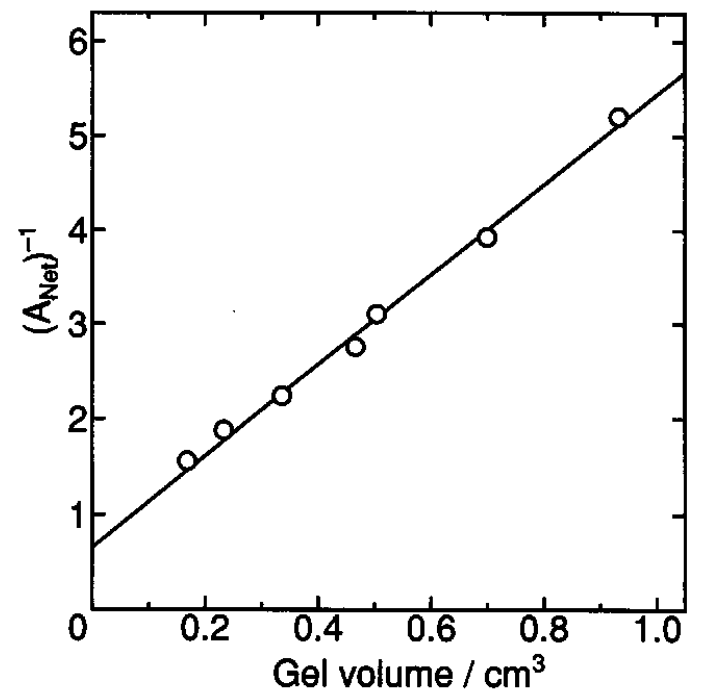

Fig. 4 Linear relationship between the gel volume and the reciprocal of net absorbance. Solution, $1.8 \times 10^{-7} \mathrm{~mol} \mathrm{dm}^{-3}$ $\mathrm{Si}, 100 \mathrm{~cm}^{3}$; gel, Sephadex G-25.

and $l$ is $0.5 \mathrm{~cm}(\bar{l}$ is $0.25 \mathrm{~cm})$. A linear relationship exists in the range where the measurement was carried out (correlation coefficient: 0.995 ). $D$ and $\bar{\varepsilon}$, obtained from the slope and the intercept for the straight line, are 730 and $23000 \mathrm{~mol}^{-1} \mathrm{dm}^{3} \mathrm{~cm}^{-1}$. Under the present conditions, $55 \%$ of the silicic acid in sample water was concentrated on the gel.

\section{Optimization of conditions}

Molybdate and sulfuric acid concentration in the yellow species formation. When the molybdate concentration is $0.02 \mathrm{~mol} \mathrm{dm}^{-3}\left(0.4 \mathrm{~g}\right.$ of $\left(\mathrm{NH}_{4}\right)_{6} \mathrm{Mo}_{7} \mathrm{O}_{24} \cdot 4 \mathrm{H}_{2} \mathrm{O}$ in $100 \mathrm{~cm}^{3}$ ), silicic acid reacts with molybdate to form $\beta$ isomer of the yellow complex in the 0.02 to $0.12 \mathrm{~mol}$ $\mathrm{dm}^{-3}$ sulfuric acid concentration range.

Amount of reducing agent. The yellow species is converted to the blue species by reduction with $\mathrm{L}$-ascorbic acid. Adding $2 \mathrm{~cm}^{3}$ of the molybdate and sulfuric acid solution and $1 \mathrm{~cm}^{3}$ of the ascorbic acid solution was adopted. The amounts added were similar to those suggested in JIS (Japan Industrial Standards). ${ }^{3}$

Sulfuric acid concentration in the blue species adsorption.

The yellow species can be reduced selectively in a sulfuric acid solution higher than $0.25 \mathrm{~mol} \mathrm{dm}^{-3}$ at the same molybdate concentration mentioned above. The blue species is extracted into butan-1-ol and the extractability increases up to $1.0 \mathrm{~mol} \mathrm{dm}^{-3}$ sulfuric acid. ${ }^{3}$ The blue species adsorbability on Sephadex G-25 may depend on the solution acidity, in analogy with the solvent extraction method. The net absorbance increased with the increase in sulfuric acid concentration (Fig. 5). The increasing net absorbance may be caused by the increase in the adsorbability for the blue species and the decrease in gel volume (due to the volume contraction of the gel). For the present method, $10 \mathrm{~cm}^{3}$ of the sulfuric acid solution was added to $100 \mathrm{~cm}^{3}$ of a sample solution. The sulfuric acid concentration is about $1.0 \mathrm{~mol} \mathrm{dm}^{-3}$. 


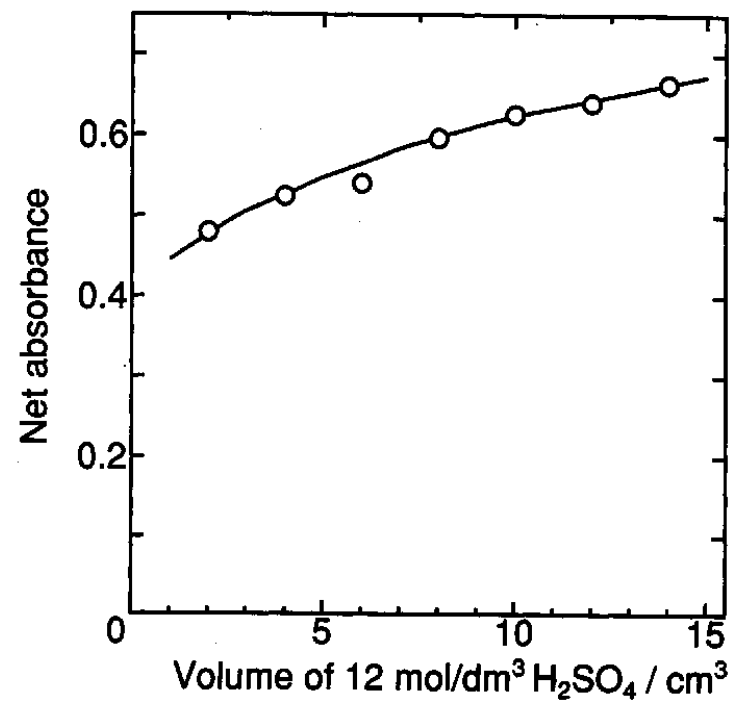

Fig. 5 Sulfuric acid concentration effect on gel-phase color development. Solution, $5 \mu \mathrm{g} \mathrm{dm}^{-3} \mathrm{Si}, 100 \mathrm{~cm}^{3}$; gel, Sephadex G-25, 0.0326g.

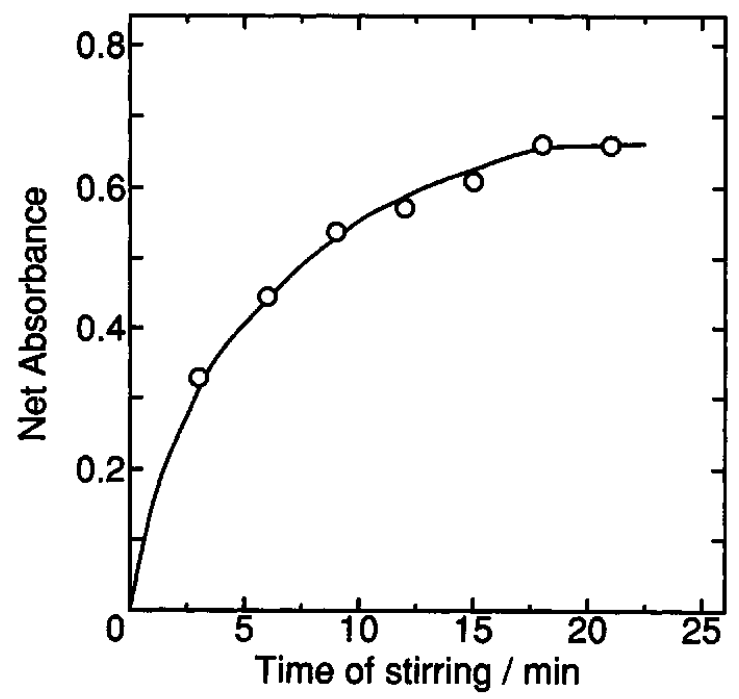

Fig. 6 Stirring time effect on gel-phase color development. Solution, $5 \mu \mathrm{g} \mathrm{dm}^{-3} \mathrm{Si}, 100 \mathrm{~cm}^{3}$; gel, Sephadex G-25, $0.0326 \mathrm{~g}$.

Stirring time. The stirring time effect on the blue species adsorption on a fine-grade gel is shown in Fig. 6. The blue species is adsorbed within $20 \mathrm{~min}$. The stirring time can be shortened by two-thirds of that employed in the previously reported method, in which a coarser gel (Sephadex G-25, medium) was used.

\section{Calibration graph}

The calibration graph is linear and could be expressed by $\Delta A=0.1224 C+\Delta A$ (for the blank), where $C$ is the silicate-silicon concentration, in $\mu \mathrm{g} \mathrm{dm}^{-3}$. $\Delta A$ (for the blank) $=0.0032$, which was obtained by measuring a water sample distilled with a PTFE subboiling distil- lation system. The sensitivity for the present method is 4.3 times higher than that for the previously reported method $^{1}$ and 150 -fold higher than that for the conventional solution method using a $10-\mathrm{mm}$ cell.

\section{Effects of foreign ions}

The foreign ion effects are shown in Table 1. Almost no ions, except for germanate and arsenate, caused more than $5 \%$ error, when present in up to 10 times that of silicic acid concentration. The amounts of interfering ions present in highly purified water are not generally more than that for silicic acid, so foreign ion effects are tolerable.

\section{Determination of silicic acid in highly purified water}

A recovery test was performed by adding known amounts of silicic acid to two water samples prepared on different dates with a Milli-Q SP system. The recovery of silicic acid was almost quantitative, as shown in Table 2. The analytical values for Milli-Q SP water samples were $0.30 \pm 0.03 \mu \mathrm{g} \mathrm{dm}^{-3}$ and $0.33 \pm 0.02 \mu \mathrm{g} \mathrm{dm}^{-3}$, and in good agreement with the analytical value reported in our previous study. ${ }^{1}$

Table 1 Effects of foreign ions on the determination of silicic acid

\begin{tabular}{lccc}
\hline $\begin{array}{c}\text { Species } \\
\text { added }\end{array}$ & $\begin{array}{c}\text { Molar ratio } \\
\text { (foreign ion/Si) }\end{array}$ & $\begin{array}{c}\text { Amount of Si } \\
\text { found } / \mu \mathrm{dm}^{-3}\end{array}$ & $\begin{array}{c}\text { Relative } \\
\text { error, \% }\end{array}$ \\
\hline $\mathrm{P}$ (V) & 1 & 3.04 & +8 \\
& 10 & 3.18 & +14 \\
$\mathrm{Fe}$ (III) & 10 & 2.62 & -7 \\
$\mathrm{Cu}$ (II) & 10 & 2.76 & -2 \\
$\mathrm{As}$ (III) & 1 & 2.74 & -2 \\
& 10 & 2.78 & -1 \\
$\mathrm{As}$ (V) & 0.1 & 2.82 & +1 \\
& 1 & 4.61 & +65 \\
$\mathrm{Ge}(\mathrm{IV})$ & 0.1 & 2.90 & +4 \\
& 1 & 4.49 & +60 \\
\hline
\end{tabular}

Sample volume, $100 \mathrm{~cm}^{3}\left(1 \times 10^{-7} \mathrm{~mol}(2.80 \mu \mathrm{g})\right.$ of $\left.\mathrm{Si} \mathrm{dm}^{-3}\right)$.

Table 2 Recovery test

\begin{tabular}{crc}
\hline \multirow{2}{*}{ Si added $/ \mathrm{ng}$} & \multicolumn{2}{c}{ Si found $/ \mathrm{ng}$} \\
\cline { 2 - 3 } & (A) & (B) \\
\hline 0 & 29 & 34 \\
50 & 77 & 80 \\
100 & 130 & 135 \\
150 & 185 & 185 \\
200 & 228 & 232 \\
250 & 278 & - \\
\hline
\end{tabular}

Sample: $100 \mathrm{~cm}^{3}$; water with a Milli-Q SP system prepared on Dec. 18, (A); Jan. 18, (B). 
Table 3 Comparison of sensitivity ${ }^{\mathrm{a}}$

\begin{tabular}{|c|c|c|c|c|}
\hline Method & $\begin{array}{c}\text { Sample } \\
\text { taken/ } \\
\mathrm{cm}^{3}\end{array}$ & $\begin{array}{c}\text { Sens./ } \\
\text { Si } \mu \mathrm{g} \\
\mathrm{dm}^{-3}\end{array}$ & $\begin{array}{l}\mathrm{DL} / \\
\mathrm{Si} \mu \mathrm{g} \\
\mathrm{dm}^{-3}\end{array}$ & Ref. \\
\hline \multicolumn{5}{|l|}{ Absorptiometry $^{b}$} \\
\hline Molybdenum Blue & - & 130 & - & - \\
\hline Molybdenum Blue $^{c}$ & 200 & 5 & - & 3 \\
\hline \multicolumn{5}{|c|}{$\begin{array}{l}\text { Gel-phase absorptiometry } \\
\text { Molybdenum Blue }^{\mathrm{d}}\end{array}$} \\
\hline Previous method & 100 & 3.5 & 0.2 & 1 \\
\hline Improved method & 100 & 0.8 & 0.04 & this work \\
\hline Malachite Green & 3.7 & 1.0 & 0.1 & 4 \\
\hline ETAAS & 0.01 & - & 2 & 5 \\
\hline ICP-AES & - & - & 5 & 6 \\
\hline
\end{tabular}

a. Si concentration giving a final absorbance of 0.1 .

b. Cell length: $1 \mathrm{~cm}$.

c. Extracted into $25 \mathrm{~cm}^{3}$ of butanol; cell length: $2 \mathrm{~cm}$.

d. Cell length: $0.5 \mathrm{~cm}$.

e. Flow analysis with flow-through cell packed with Sephadex LH gel.

\section{Comparison of sensitivity with other methods}

The detection limit, defined as the concentration which produces an absorbance equal to three times the standard deviation of the reagent blank absorbance, was 0.04 $\mu \mathrm{g} \mathrm{dm}^{-3}$ of $\mathrm{Si}$. A comparison of the sensitivities of various analytical methods is shown in Table 3 . The present method is more sensitive than the other analytical methods for silicic acid which have ever been reported.

The authors thank Dr. K. Matsumi, Dr. T. Yuasa and Dr. T. Okuda for helpful discussions and encouragement throughout this work.

\section{References}

1. K. Yoshimura, M. Motomura, T. Tarutani and T. Shimono, Anal. Chem., 56, 2342 (1984).

2. H. Waki and Y. Miyazaki, Polyhedron, 8, 859 (1989).

3. "Testing Method for Determination of Silica in Highly Purified Water", Committee for Japan Industrial Standard, Tokyo, 1990.

4. K. Yoshimura and U. Hase, Analyst [London], 116, 835 (1991).

5. M. Suzuki, "Genshikyukou Bunsekihou (Atomic Absorption Spectrometry, in Japanese)", Kyoritsu, Tokyo, 1984.

6. T. Miwa, Y. Noguchi and A. Mizuike, Anal. Chim. Acta 204, 339 (1988).

(Received September 14, 1992) (Accepted November 16, 1992) 